УДК 82I.I6І.І

ББК $83.3(2 \mathrm{Poc}=\mathrm{Pyc}) 6$
КТО ТАКОЙ ВАСИЛИЙ ТРАВНИКОВ?

К ВОПРОСУ О СОПРЯЖЕНИИ

МИСТИФИКАЦИИ И ИСТОРИИ

ЛИТЕРАТУРЫ

\author{
(C) 2018 г. А. Такеда \\ Университет Тояма, \\ Тояма, Япония \\ Дата поступления статьи: 3г октября 2017 г. \\ Дата публикации: 25 июня 2018 г.
}

DOI: IO.22455/2500-4247-2018-3-2-I64-I73

Аннотация: «Жизнь Василия Травникова» (1936) В. Ходасевича является литературной мистификацией, в которой автор создал вымышленного герояпоэта, предшественника Пушкина, и правдоподобно рассказал о его жизни и творчестве. Этот герой - своего рода двойник Ходасевича, который критикует литературу допушкинского времени и начальный период творчества Пушкина и претендует на создание «традиции Травникова», сопоставимой с «пушкинской традицией», что соответствует разным попыткам «мифотворчества» В литературе модернизма. Такое преображение авторского «я», конечно, находится вне рамок автобиографии, однако образ Василия Травникова намного ярче характеризует самого Ходасевича, его поэтическое творчество и мировоззрение, чем, например, знаменитые мемуары «Некрополь».

ключевые слова: Ходасевич, Пушкин, литературная мистификация, история литературы, мифотворчество.

Информация об авторе: Акифуми Такеда - кандидат филологических наук, доцент, Гуманитарный факультет университета Тояма, 3190 Гофуку, Тояма-си, Тояма, 930-8555, Япония.

E-mail: takeda@hmt.u-toyama.ac.jp

Для цитирования: Такеда А. Кто такой Василий Травников? К вопросу о сопряжении мистификации и истории литературы // Studia Litterarum. 20I8. Т. 3, № 2.

C. I64-I73. DOI: I0.22455/2500-4247-2018-3-2-I64-I73 


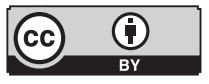

This is an open access article distributed under the Creative Commons Attribution 4.0 International (CC BY 4.0)

\section{WHO IS VASILY TRAVNIKOV? BETWEEN LITERARY HOAX AND LITERARY HISTORY}

\author{
(C) 20I8. A. Takeda \\ University of Toyama, \\ Toyama, Japan \\ Received: October 3I, 2017 \\ Date of publication: June 25, 2018
}

\begin{abstract}
The Life of Vasily Travnikov (1936) by V. Khodasevich is a literary hoax that introduces a fictional poet, the predecessor of Pushkin, and plausibly tells about his life and work. This character is Khodasevich's twin of a kind who criticizes literature of the pre-Pushkin era and the initial period of Pushkin's literary career and claims to create a "Travnikov tradition" comparable to the "Pushkin tradition." Thus, The Life of Vasily Travnikov is an attempt at "myth creation" typical for the modernist literature. Though the image of Travnikov is not purely autobiographical, it gives an idea about Khodasevich, his poetic work and worldview better than, for example, his famous memoirs Necropolis.
\end{abstract}

Keywords: Khodasevich, Pushkin, literary hoax, literary history, myth creation.

Information about the author: Akifumi Takeda, $\mathrm{PhD}$ in Philology, Associate Professor, Faculty of Humanities, University of Toyama, 3190 Gofuku, Toyama-shi, Toyama, 930-8555, Japan.

E-mail: takeda@hmt.u-toyama.ac.jp

For citation: Takeda A. Who is Vasily Travnikov? Between Literary Hoax and Literary History. Studia Litterarum, 2018, vol. 3, no 2, pp. 164-I73. (In Russ.)

DOI: I0.22455/2500-4247-20I8-3-2-I64-I73 
«Жизнь Василия Травникова» Владислава Ходасевича [II] основана на сопряжении мистификации и истории литературы. В этом литературном сочинении автор создал вымышленного героя - поэта, предшественника Пушкина, и правдоподобно рассказал о его жизни и творчестве.

«Жизнь Василия Травникова» написана как исторический очерк, точнее, как биография неизвестного поэта. В основном, как и многие исторические сочинения, она написана от третьего лица.

Тем не менее в конце повествования появляется «я» рассказчика, которого можно отождествить с самим автором, и, таким образом, документальное повествование от третьего лица плавно переходит в авторское воспоминание и размышление от первого лица.

Историю Василия Травникова мы узнаем из уст автора, который якобы нашел архив поэта и рассказывает нам о нем. Таким образом, эта мистификация носит такой же мемуарный характер, как и известный «Некрополь», и другие автобиографические очерки Ходасевича.

Это - лишь первый план автобиографического начала в «Травникове». В этом создании Ходасевича скрывается еще и второй план, который намного важнее первого, и именно о нем пойдет речь далее.

В образах героев - не только поэта Василия, но и его отца Григория - встречается довольно много параллелей с чувствами и переживаниями самого Ходасевича. Чем внимательнее мы читаем текст, тем больше обнаруживаем аллюзий и даже скрытых цитат из его собственных стихов. 
Об этих параллелях автору статьи доводилось говорить в докладе, с которым он выступал в Японий. Позволим себе ограничиться здесь лишь кратким перечислением.

1. Выбор времени. Герой родился в 1785 г., почти ровно за сто лет до Ходасевича, однако стиль его общения с людьми, прозорливые и тонкие наблюдения над литераторами того времени явно связаны с характером, талантом и жизненным опытом самого Ходасевича.

2. Образы главных героев. Василия Травникова без всяких натяжек можно сравнить с идеализированным образом молодого Ходасевича, а отца Травникова - с умудрённым, обожжённым временем Ходасевичем позднейших эмигрантских времён.

3. Выбор места. Автор связывает героев с памятными местами своей жизни. Здесь наиболее широко представлены московские улицы, по тем или иным причинам важные и знаменательные для биографии самого Ходасевича.

4. Память о настоящем, а не вымышленном друге (Муни). Поэту Василию Травникову приписывается отрывок из стихов Муни² [II, с. II5]. Образ Муни не просто прихотливо скрывается за героями этого повествования, но постоянно присутствует в подтексте.

5. Взгляды автора на русскую литературу. Об этом следует сказать особо, поэтому мы вернемся к этому пункту после обсуждения ряда моментов.

«Василий Травников» содержит второй сюжетный план, в основу которого положены собственные мысли и переживания Ходасевича. Наиболее существенной для современного исследователя представляется задача определить, с чем связаны разнообразные параллели, открывающиеся читателю в этом произведении?

Я хотел бы сосредоточить внимание на одной очень важной для Ходасевича теме. Это тема - «разговор с Пушкиным». Ходасевич продолжает и развивает этот своеобразный, исключительно важный для него «раз-

I Круглый стол «Об автобиографическом описании в русской культуре в первой половине XX века», 66-я ежегодная конференция Японской ассоциации русистов. Университет Хоккайдо (23. Іо. 20І7). См.: Хроника // Бюллетень Японской ассоциации русистов. №. 49. Токио, 2017. С. $270-277$.

2 Стихотворение «Шмелей медовый голос...» (1915?) [7, с. 95]. О дружбе Ходасевича и Муни см.: [7, с. 259-384]. 
говор» не только в «Травникове», но и в своих исследовательских работах [2; го]. Однако в «Травникове» он построен совсем по-другому.

Скрываясь за мистификацией, как за маской, он на сей раз ведет свой «разговор с Пушкиным» намного более полемично, чем прежде, и ищет (точнее, проверяет) свои «корни», свое происхождение как русского литератора, создавая в итоге в высшей степени оригинальный и символический «миф Травникова».

В «Жизни Василия Травникова» Ходасевич на удивление сурово относится к любимому им Пушкину. Василий Травников в качестве alter ego Ходасевича совершенно не ценит «Руслана и Людмилу». Он говорит, что «молодой автор тратит свои дарования на низкое зубоскальство», ехидно (и в то же время не без оснований) добавляя: «Следствие воспитания, коему начало положено сочинениями вроде “Опасного соседа” [II, c. II4].

Столь едкое, даже убийственное замечание отпущено, конечно, по адресу не одного лишь молодого Пушкина. Это ядовитая стрела поражает не только ранние сочинения Пушкина; она подрывает и авторитет его учителей и наставников (и французских, и русских), метит и в Карамзина, и в Жуковского, и в других. «Жизнь Василия Травникова» - это произведение, в котором исподволь, но жёстко критикуется вся допушкинская литература, осуждается и сам Пушкин как автор «Руслана и Людмилы». Единственный из писателей того времени, кто совершенно избежал здесь нападок - Державин, о котором в тексте нет ни одного слова.

В «Жизни Василия Травникова» Ходасевич, можно сказать, по-стариковски не приемлет молодого, брызжущего энергией, как шампанским, задора Пушкина, пушкинской вольности и фривольности. Брюзжа, он называет его веселость и шутливость зубоскальством. Из повествования следует, что Травников умер в г820 г. Исходя из этого, критика Пушкина Травниковым никак не может быть всеобъемлющей. У Пушкина все еще впереди, а условный Травников уже закончил свой путь. И тем не менее и это исключительно важно для исследователя - никому не известный поэт Травников резко противопоставлен Пушкину, у которого впереди все его грандиозные свершения.

Что означает это противопоставление? Герой Ходасевича, если сравнивать его с Пушкиным, больше всего отличается от последнего вернее было бы сказать, от первого! - своими «воззрениями на судьбу». 
В пушкинских произведениях не раз подчеркивается и выпукло обрисовывается, как судьба играет людьми. Однако, как всегда, у светлого, солнечного Пушкина надежда на примирение с коварной судьбой, как и просто надежда, не исключаются. Именно благодаря этой надежде в мире Пушкина сохраняется и царствует гармония³ [9].

В случае же Травникова нет никакой надежды на примирение с судьбой, тем более, на милости от судьбы; их нет и в помине. Василий Травников испытывает все новые и новые несчастья и, уже не ища утешения в жизни, «из единой гордости» выносит все страдания до конца4. Для него «игра судьбы» изначально и до конца несправедлива и враждебна человеку. Безжалостный мир страшен и полон дисгармонии.

В таком взгляде на мироздание и на человеческую судьбу трудно не увидеть трагическое восприятие мира позднего Ходасевича. И, по нашему мнению, это именно он, а не мифический Травников спорит таким образом со своим любимым Пушкиным. Василий Травников - своего рода двойник Ходасевича, и этот двойник, при всей своей поэтической близости к Пушкину, остро ощущает свое отличие от него. Можно даже сказать, что это антипод Пушкина. Таковы результаты поиска Ходасевичем своих «корней», своего места в русской литературе. При всей его любви к Пушкину, он отчётливо показывает свою несхожесть с ним, несогласие во многих творческих и мировоззренческих установках 5 . Одновременно он возводит своего героя на высоту Пушкина, ставит его наравне с Пушкиным, и смело претендует на создание «традиции Травникова», к которой причастен и он сам ${ }^{6}$.

3 Особенно отчетливо это видно в повестях «Метель» и «Капитанская дочка».

4 В качестве подтверждения в текст включены стихотворение Травникова («Я в том себе ищу и гордости и чести, / Что утешение отверг с надеждой вместе...» [II, c. II5]) и эпитафия: «Василий Травников лежит под камнем сим. / Прохожий! лживых слёз не проливай над ним» [II, с. II3].

5 Но при этом не следует забывать слова С. Гандлевского, который отмечает, что «самые разные писатели - от Горького до Набокова - считали Владислава Ходасевича наиболее последовательным продолжателем пушкинской традиции в отечественной поэзии. Но Пушкина как никого из русских поэтов отличает чрезвычайное богатство лирической мимики и интонационных регистров. Из этого многообразия Владиславу Ходасевичу ближе всего по темпераменту и складу дарования пришлась тональность Вальсингамова гимна чуме - музыки праздничной гибели, “упоения... бездны мрачной на краю”» [3, с. 5-6].

6 О своем герое Ходасевич говорит: «Впоследствии более других приближаются к Травникову Боратынский и те русские поэты, которых творчество связано с Боратынским. 
Такая попытка создания вымышленной традиции вписывается в ряд различных попыток «мифотворчества» в литературе модернизма. У Хорхе Луиса Борхеса есть эссе, которое называется «Кафка и его предшественники». «Жизнь Василия Травникова» чем-то напоминает это эссе Борхеса.

Создание вымышленной традиции естественно порождает переосмысление истории. «Жизнь Василия Травникова» как бы являет собой комплексную реминисценцию всей русской поэзии, с глубоко своеобразным и весьма критическим, можно сказать - придирчивым взглядом на нее.

С какой целью Ходасевич прибегает к попытке нарисовать столь широкую и вместе с тем целостную картину? Думаю, здесь можно предположить две причины.

Первая причина, вполне возможно, заключается в том, что Ходасевич был русским поэтом, национальная принадлежность которого могла бы насторожить любого национально-ориентированного приверженца империи и имперского сознания, каких в те времена, как и в любые другие, было немало. Полу-поляк, полу-еврей, католик по вероисповеданию, он должен был осознавать, какими глазами и с какими чувствами - пусть порой и затаенными - рассматривали его многие литераторы тех дней. Очень возможно, что горечь, во многом окрашивающая взгляды Ходасевича на русскую литературу, в определенной степени связана с этим обстоятельством.

Вторая причина - это предчувствие конца классической русской литературы, которое Ходасевич мучительно и безысходно переживает в период эмиграции в тридцатые годы [12; г3]. Охваченный этими трагическими чувствами, Ходасевич написал «Жизнь Василия Травникова» как собственную «альтернативную историю» русской литературы, как завершающий окончательный взгляд на нее. Вероятно, на основании этого и стало возможным подойти к этой теме свободно, карнавально-раскованно.

Быть может, те, кого принято считать учениками Боратынского, в действительности учились у Травникова?» [ІІ, с. II5]. Но здесь самое время вспомнить, что Андрей Белый говорил о близости поэзии Ходасевича к поэзии Боратынского [г], и это было сразу признано другими критиками [6]. 


\section{Русская литература / А. Такеда}

Безусловно, преображение авторского «я» в «Жизни Василия Травникова» не дает возможности прямо связывать легендарного Травникова с самим Ходасевичем, с его биографией. Но образ поэта Травникова в этом сочинении в некоторых отношениях характеризует поэта Ходасевича не хуже, чем, например, в его знаменитых мемуарах «Некрополь». О том, что эта характеристика сделана более изощренно и тонко, говорить не приходится. 


\section{Studia Litterarum /20I8 том 3, № 2}

\section{Список литературы}

I Белый А. Рембрандтова правда в поэзии наших дней (О стихах В. Ходасевича) // Записки мечтателей. № 5. Пг.: Алконост, г922. С. І36-г39.

2 Бочаров С. «Памятник» Ходасевича // Сюжеты русской литературы. М.: Языки русской культуры, 1999. С. 415-47І.

3 Гандлевский С. Орфей в подземке // Ходасевич В.Ф. Выбор Сергея Гандлевского. М.: Б.С.Г.-Пресс, 2016. С. 5-23.

4 Давыдов С. Шишки на Адамову голову: о мистификациях Ходасевича и Набокова // Звезда. 2002. № 7. С. 194-198.

5 Зорин А. Начало // Ходасевич В.Ф. Державин. М.: Книга, I988. С. 5-28.

6 Иванов Г. В защиту Ходасевича // Иванов Г. Собр. соч.: в 3 т. М.: Согласие, 1994. T. 3. С. 5II-5I5.

7 Киссин С. (Муни) Легкое бремя: Стихи и проза; Переписка с В.Ф. Ходасевичем. М.: Август, I999. $4 \mathrm{I} 6$ с.

8 Назаренко М. «Жизнь Василия Травникова» В. Ходасевича: поэтика мистификации. // URL: http://www.hodasevich.su/about/zhizn-vasiliya-travnikova-vkhodasevicha-poetika-mistifikatsii.html (дата обращения: 29.Iо.20I7).

9 Пушкин А.С. Собр. соч.: в го т. М.: ГИХЛ, г96о. Т. 5.663 с.

Iо Сурат И. Пушкинист Владислав Ходасевич. М.: Лабиринт, I994. II2 c.

II Ходасевич В.Ф. Собр. соч.: в 4 т. М.: Согласие, І997. Т. 3. С. 95-II5.

I2 Шубинский В. Владислав Ходасевич: Чающий и говорящий. М.: Молодая гвардия, 20І2. 523 с.

I3 Bethea David M. Khodasevich: His Life and Art. Princeton University Press, I983. $380 \mathrm{p}$. 


\section{References}

I Belyi A. Rembrandtova pravda v poezii nashikh dnei (O stikhakh V. Khodasevicha) [Rembrandt's truth in the poetry of our days (About poems of V. Khodasevich)]. Zapiski mechtatelei. No 5 [Dreamers' notes. No. 5]. Petrograd, Alkonost Publ., I922, pp. I36-I39. (In Russ.)

Bocharov S. «Pamiatnik» Khodasevicha [“Monument” by Khodasevich]. Siuzhety russkoi literatury [Russian literatury plots]. Moscow, Jazyki russkoi kul'tury Publ., I999, pp. 4I5-47I. (In Russ.)

3 Gandlevskii S. Orfei v podzemke [Orpheus in the underground]. Khodasevich V.F. Vybor Sergeia Gandlevskogo [Sergei Gandlevskii’s choice]. Moscow, B.S.G-Press Publ., 2016, pp. 5-23. (In Russ.)

Davydov S. Shishki na Adamovu golovu: o mistifikatsiiakh Khodasevicha i Nabokova [Cones on Adam's Head: On literary hoaxes by Khodasevich and Nabokov]. Zvezda, 2002, no 7, pp. 198-I98. (In Russ.)

Zorin A. Nachalo [The Beginning]. Khodasevich V.F. Derzhavin [Derzhavin]. Moscow, Kniga Publ., I988, pp. 5-28. (In Russ.)

6 Ivanov G. V zaschitu Khodasevicha [In defence of Khodasevich]. Ivanov G. Sobranie sochinenii: $v 3 t$. [Ivanov G. Collected works: in 3 vols.]. Moscow, Soglasie Publ., I994, vol. 3, pp. 5II-5I5. (In Russ.)

Kissin S. (Muni) Legkoe bremiia: Stikhi i proza; Perepiska s V.F. Khodasevichem [Easy burden: poems and prose; Correspondence with V.F. Khodasevich]. Moscow, Avgust Publ., I999. 4I6 p. (In Russ.)

8 Nazarenko M. «Zhizn' Vasilii Travnikova» V. Khodasevicha: poetika mistifikatsii [The Life of Vasily Travnikov by V. Khodasevich: The poetics of the hoax]. Available at: http://www.hodasevich.su/about/zhizn-vasiliya-travnikova-v-khodasevichapoetika-mistifikatsii.html (Accessed 29 October 20I7). (In Russ.)

9 Pushkin A.S. Sobranie sochinenii: $v$ ro t. [Pushkin A.S. Collected works: in Io vols.]. Moscow, GIKHL Publ., I960. Vol. 5. 663 p. (In Russ.)

IO Surat I. Pushkinist Vladislav Khodasevich [Vladislav Khodasevich as a Pushkin scholar]. Moscow, Labirint Publ., I994. II2 p. (In Russ.)

II Khodasevich V. F. Sobranie sochinenii: $v 4 t$. [Collected works: in 4 vols.]. Moscow, Soglasie Publ., I997, vol. 3, pp. 95-II5. (In Russ.) Shubinskii V. Vladislav Khodasevich: Chaiuschii i govoriaschii [Vladislav Khodasevich: desiring and speaking]. Moscow, Molodaia gvardiia Publ., 20I2. 523 p. (In Russ.)

I3 Bethea David M. Khodasevich: His Life and Art. Princeton, Princeton University Press, I983. 380 p. (In English) 